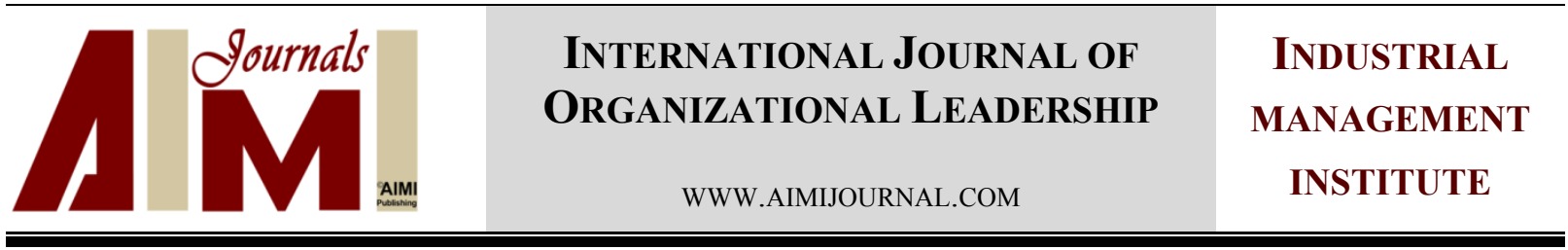

\title{
A content analysis of servant leadership studies
}

\author{
Burcu Yiğit ${ }^{*}$, Serdar Bozkurt ${ }^{2}$ \\ ${ }^{1}$ Y 1 ldiz Technical University, Institute of Social Sciences \\ ${ }^{2}$ Department of Business Administration, Faculty of Economics and Administrative Sciences, Yıldız Technical \\ University
}

\begin{abstract}
Keywords:

Servant Leadership,

Content Analysis

Received

09 September 2016

Received in revised form

27 December 2016

Accepted

08 January 2017

Correspondence:

brcygt@hotmail.com

The aim of this study was to evaluate the articles has been written about servant leadership between 2000 and 2016 years (until August). For this purpose, four world-known electronic databases were identified in this study. These databases are EBSCO $(F=35)$, Sage $(F=$ 26), Science Direct $(F=8)$ and Emerald $(F=27)$. Generally, 96 articles were gathered from these databases about servant leadership. These articles were analyzed according to journal name, publication year, country, sample size, type of research, data collection tool(s), and data analysis method. Using the content analysis method, the frequency distribution of data, descriptive statistics, and percentage analysis were determined. When the results of the study were examined, it was concluded that the most published journal was "Leadership and Organizational Development Journal" during 2015 and 2016 in the United States. The sample size ranged from 1 to 500 . To collect data, quantitative research and survey were used. Factor analysis, correlation, and regression analysis were used to analyze the obtained data.
\end{abstract}

CAIMI Journals Many leadership theories have examined the relationship between behavioral and situational contexts. There is an approach to the secret of success in the context of these variables. In today's organizations, it still remains as a main issue that the leaders should focus on the behavior of their followers or investigate their situational characteristics when they perform their leadership styles. It is important in the realm of servant leadership that the leaders realize their followers' well-being and promote their wellness at the same time. The concept of servant leadership was first introduced by Greenleaf (1977) in his book "The Servant as Leader. 
Having a vision for the future, servant leaders try to empower and serve their followers in order to provide a positive environment in their organization. This study aims to provide comprehensive information on the concept of servant leadership and its characteristics.

\section{The Literature Review}

With the advent of people-oriented management style in today's competitive business world, leadership styles begin to change day by day. The term servant leadership as one of the new leadership styles was initially introduced by Robert Greenleaf in 1970 (Zhou \& Miao, 2014). According to Greenleaf, the servant-leader tries to serve to his followers first and this starts with his natural feeling that wants to serve(Greenleaf, 1977). Having empathy, the servant leaders try to humble and devote themselves to their followers. They attempt to focus on their followers' expectations and needs rather than their own selves (Coşkunlar, 2011). According to Spears (1996), based on teamwork and community, servant-leaders respect and involve their followers in decision making and planning processes (Top, Öğe, Atan, \& Gümüş, 2015). Serving the followers is the most important aspect of the servant leadership (Chen, Chen, \& $\mathrm{Li}$, 2013). There is a large consensus in the literature that servant-leaders focus on serving their followers and think firstly about them. In addition to serving aspect, servant leadership has different dimensions in different studies. Ehrhart (2004) determined seven dimensions of servant leadership in his study. These dimensions involve forming the relationships with followers, empowering and helping them to grow and succeed, behaving ethically, demonstrating their conceptual skills, thinking firstly about their followers, and creating values (Ehrhart, 2004; Hunter et al., 2013). Having these properties, the servant-leaders can help and support their followers and also contribute to the organization within an ethical framework. Other five dimensions of servant leadership determined by Barbuto and Wheeler (2002) including altruistic calling, emotional healing, wisdom, persuasive mapping, and organizational stewardship. Altruistic calling means the leader determine his/her followers' interests and desires first and then make a positive difference in their life. Emotional healing refers to the leader's commitment towards his followers and determines his close relationship with others. Wisdom dimension refers to the desire to have a vision of the future because a servant-leader has to predict what will be happening both within and outside of the organization. Persuasive mapping refers to the ability of leaders to understand and influence others. Finally, organizational stewardship means taking the responsibility for the community and also contributes to the society (Barbuto, Gottfredson, \& Searle, 2014). The aim of this study was to evaluate the articles from 2000 to 2016 on servant leadership with content analysis. Totally 96 articles were reached from EBSCO, Emerald, Sage, Science Direct databases. The starting point of this study is the lack of an overall assessment of servant leadership. Determining the importance of research about servant leadership and directing researchers to this area increase the importance of this study. This study was conducted to investigate the concept of servant leadership through a variety of variables. The analyses of published articles on servant leadership based on journal names, countries, and time were discussed in this study. 


\section{Research Questions}

In this study, it is intended to make analyses of different articles and also reveal the existing position of servant leadership in the literature. In line with the discussion above, the following research questions were formulated:

- How is the distribution of servant leadership articles according to journal names?

- How is the distribution of servant leadership articles according to publication years?

- How is the distribution of servant leadership articles according to countries?

- How is the distribution of servant leadership articles according to sample sizes?

- How is the distribution of servant leadership articles according to types of research?

- How is the distribution of servant leadership articles according to data collection tools?

- How is the distribution of servant leadership articles according to data analysis methods?

\section{Method}

As a qualitative data analysis technique, the content analysis research design was used in this study. Qualitative research involves with both individual experiences and how they interpret them. This is a post-positivist research approach. Qualitative research shares certain common features and also provides more information about social events and cases (Büyüköztürk, KılıçÇakmak, Akgün, Karadeniz, \& Demirel, 2012). The population of this study involves with articles written regarding servant leadership in EBSCO, Emerald, Sage, Science-Direct databases. The sample of this study includes 96 articles that have open access to servant leadership from 2000 to 2016 (until August). These articles were analyzed according to journal name, publication year, country, sample size, type of research, data collection tool(s), and data analysis method.The content analysis method which considered as widely used method in social sciences can outline the smaller content categories systematically and then encode them based on systematic certain rules and repeatable patterns (Büyüköztürk et al., 2012). The basic idea in the content analysis is to explain data collected category and reach concepts and relationships. For this purpose, the data were conceptualized and then emerging concepts are organized and determined in a logical way. Consequently, the process ended with the findings and the interpretations (Yıldırım \& Şimşek, 2006). First, the process of screening and selecting criteria for servant leadership was determined. Therefore, some codes were allocated to various themes and then the data was arranged and grouped according to these themes. Finally, the data were thoroughly digitized and findings were reviewed. The researchers carefully observe the object of these cases and identify the validity in qualitative research (Yıldırım \& Şimşek, 2006). The predictive validity of the content analysis is related to the compliance between the purposes and devices. The content analysis requires reaching the goal without breaking the cases and messages. The reliability especially depends on the coding process. This situation is related to the reliability of encoders and categories. The reliable encoder requires that the different encoders use the same codes in the same text and way (Bilgin, 2006). To ensure the reliability and validity of the research, it is essential to create the proper categories and coding structures by considering the relevant structure and literature review. Data categories and codes were performed by two researchers that were working each other independently. Finally, 
the codes and the categories were compared. The articles that were not approved by the researchers excluded from the assessment.

\section{Results}

The study was analyzed 96 articles from four databases including EBSCO, Emerald, Sage, and Science Direct. These selected articles published from 2000 to 2016 (until August). Journal names, publication years, countries, sample sizes, data collection tools, research types were analyzed in this study. The servant leadership articles are mostly seen in journals about leadership. Servant leadership studies are particularly relevant to leadership journals. This concept is not included in the journals of other disciplines. Table 1 presents the distribution of articles according to journal names.

Table1

Distribution of Articles According to Journal Names

\begin{tabular}{lcc}
\hline List of Journals & Frequency & Percent \\
\hline Leadership \& Organizational Development & 14 & 14.6 \\
Journal of Leadership \& Organizational Studies & 8 & 8.3 \\
The Leadership Quarterly & 7 & 7.2 \\
Journal of Business Ethics & 6 & 6.3 \\
Leadership & 5 & 5.3 \\
Journal of Personal Selling \& Sales Management & 4 & 4.2 \\
Others* & 52 & 54.1 \\
Totally & 96 & 100 \\
\hline
\end{tabular}

*Note. Published only one article was expressed together

Table 2 shows the distribution of articles according to their publication years. There was generally an increase in the number of articles related to servant leadership after 2011. The largest increase occurred respectively in 2014 (12 articles; 12.5 per cent) and 2015 (14 articles; 14.6 per cent). The awareness and interest in servant leadership principles has been increased in recent years. Based on the increase in the last 4 years, it was predicted that the number of articles would be increased in the future.

Table 2

Distribution of Articles According to Publication Year

\begin{tabular}{ccc}
\hline Year of Publication & Frequency & Percent \\
\hline 2000 & - & - \\
2001 & 1 & 1 \\
2002 & 5 & 5.2 \\
2003 & 1 & 1 \\
2004 & 4 & 4.2 \\
2005 & 3 & 3.1 \\
2006 & 3 & 3.1 \\
2007 & 2 & 2.1 \\
2008 & 2 & 2.1 \\
2009 & 7 & 7.3 \\
2010 & 6 & 6.3 \\
2011 & 8 & 8.3 \\
2012 & 11 & 11.5 \\
2013 & 7 & 7.3 \\
2014 & 12 & 12.5 \\
2015 & 14 & 14.6 \\
2016 & 10 & 10.4 \\
Total & 96 & 100 \\
\hline
\end{tabular}


Table 3 demonstrated that the distribution of articles about servant leadership according to the countries. This type of article was mostly seen in the United States (54 articles; 56.3 per cent). The second country was China that has published 8 articles about servant leadership (about 8.3 per cent) In Turkey, the number of articles also were at an acceptable rate. Totally, the concept of servant leadership was usually discussed and examined in the context of Western culture.

Table 3

Distribution of Articles about Servant Leadership According to the Countries

\begin{tabular}{lcc}
\hline Countries & Frequency & Percent \\
\hline United States * & 54 & 56.3 \\
China & 8 & 8.3 \\
Netherlands * & 5 & 5.2 \\
New Zealand & 3 & 3.1 \\
Turkey & 3 & 3.1 \\
Others (1 or 2 units articles totally) & 23 & 24 \\
Total & 96 & 100 \\
\hline
\end{tabular}

*Note. It was applied in two countries at the same time.

Table 4 reflects the distribution of articles about servant leadership according to their sample sizes. The preferred sample size for published articles about servant leadership is related to the range of 1-500 (about 74.3 per cent). Therefore, large sample size studies are considered more important for the future studies.

Table 4

Distribution of Articles about Servant Leadership According to Sample Sizes

\begin{tabular}{lcc}
\hline Sample Sizes & Frequency & Percent \\
\hline $1-500$ & 52 & 74.3 \\
$501-1000$ & 13 & 18.6 \\
$1001-1500$ & 4 & 5.7 \\
1501 and above & 1 & 1.4 \\
Total & 70 & 100 \\
\hline
\end{tabular}

* Note. 26 articles (theoretical context) were not included in the study

Table 5 shows the different types of research in the selected articles. According to Table 5, quantitative research allocates 58.3 per cent of selected articles (about 58. Per cent) according to their research types. The second most used research type is theoretical articles that dedicated about 27.1 per cent to themselves. It was seen that the servant leadership was mostly handled with theoretical context and quantitative studies. In this context, the concept of servant leadership can be primarily supported by qualitative studies in the future studies.

Table 5

Different Types of Research in the Articles

\begin{tabular}{lcc}
\hline Types of Research & Frequency & Percent \\
\hline Quantitative & 56 & 58.3 \\
Qualitative & 8 & 8.3 \\
Mix method (quantitative \& qualitative) & 6 & 6.3 \\
Theoretical & 26 & 27.1 \\
Total & 96 & 100 \\
\hline
\end{tabular}


Table 6 demonstrates the distribution of data gathering tools. According to Table 6 , the survey is the most commonly used tool for collecting data which allocates 55 articles or 78.6 per cent to itself. The second most common source of data collection was interview.

Table 6

Distribution of Data Gathering Tools

\begin{tabular}{lcc}
\hline Data Gathering Techniques * & Frequency & Percent \\
\hline Survey & 55 & 78.6 \\
Interview & 8 & 11.4 \\
Secondary Data & 4 & 5.7 \\
Success Story & 1 & 1.4 \\
Observation & 2 & 2.9 \\
Total & 70 & 100 \\
\hline
\end{tabular}

*Note. Multiple data collection tools were used simultaneously in some of the articles

Table 7 shows different data analysis methods used in the articles about servant leadership such as factor analysis, correlation, and regression analysis and their frequency and per cent, respectively. The programs such as AMOS and LISREL are mainly used for the structural equation modeling (SEM) especially in large-scale studies.

Table 7

Data Analyses Methods Used in the Articles about Servant Leadership

\begin{tabular}{lcc}
\hline Data Analysis Technique * & Frequency & Percent \\
\hline Factor Analysis (Confirmatory \& Exploratory) & 34 & 36.2 \\
Correlation & 21 & 22.3 \\
Multiple \& Linear Regression & 16 & 17.0 \\
ANNOVA & 7 & 7.4 \\
MANOVA & 6 & 6.4 \\
Descriptive & 3 & 3.2 \\
Discriminate Analysis & 3 & 3.2 \\
MANCOVA & 2 & 2.1 \\
T-test & 2 & 2.1 \\
Total & 94 & 100 \\
\hline
\end{tabular}

*Note. Multiple data analysis methods were used simultaneously in some articles.

\section{Discussion and Conclusion}

The concept of servant leadership was introduced by Robert Greenleaf in 1977. This term states the way a leader serves and educates his/her followers or employees. It initially emerged over the last 15 years especially in the organizational behavior studies. This study tried to use content analysis to review the past literature of the servant leadership. The selected articles about servant leadership which obtained from four different databases were considered from 2000 to 2016. The selected articles were evaluated according to journal names, publication years, countries, sample sizes, research types, data collection tools, and data analysis methods. Despite being a new research topic, it was determined totally 96 articles about the servant leadership. The results revealed that "Leadership and Organizational Development" journal with 14 articles was the commonly used journal. The second journal was "Leadership and Organizational Studies". These journals covered the concept of leadership. The findings also indicated that 70 and 26 of these articles allocated to practical and theoretical studies. This showed an increase after the year 2011. The largest increase occurred in 2015 and 2016, 
respectively. The majority of articles about servant leadership were published in the United States. The following country was China that allocated the large number of articles about servant leadership to itself. The preferred sample size for articles covered the range of 1 to 500 . The popular type of research in these articles was quantitative. Also, qualitative research and mix methods were used in the studies. According data analysis, the programs such as AMOS and LISREL were mainly used for the SEM analyses. Furthermore, the findings showed that survey was commonly used for collecting data. Factor analyses and correlation were commonly used data analysis methods based on the obtained results. It is concluded that the concept of servant leadership was related to the organizational behavior and other disciplines. In addition, it is thought that studying the concept of servant leadership in different sectors provides opportunity of measuring it. Therefore, some specific measurement tools should be developed and applied based on the cultural differences. This study suffers from some drawbacks. First, this study just studied the concept of servant leadership. Second, the content analysis was applied only from 2000 to 2016 . Third, only content analysis method was used to screen the articles. Future studies can also focus on both quantitative and qualitative methods in different sectors. Finally, the sample size and the number of databases were limited. Researchers can reach much more comprehensive results through examining of larger sample sizes and more databases.

\section{References}

Barbuto, J. E., Gottfredson, R. K.,\&Searle, T. P. (2014). An examination of emotional intelligenceasan antecedent of servant leadership. Journal of Leadership \&Organizational Studies, 21(3), 315-323.

Barbuto, J. E., \& Wheeler, D. W. (2002). Becoming a servant leader: Do you have what it takes? Lincoln, NE: University of Nebraska.

Bilgin, N. (2006). Sosyal bilimlerde içerik analizi: Tekniklerve ornek calışmalar. Ankara:Siyasal Kitabevi.

Büyüköztürk, Ş., Kılıç-Çakmak, E., Akgün, Ö.E., Karadeniz, Ş.,\& Demirel F. (2012). Bilimsel araştırma yöntemleri. Ankara: Pegem Akademi.

Chen, C., Chen, C. V.,\& Li, C. (2013). The influence of leader's spiritual values of servant leadership on employee motivational autonomy and eudemonicwell-being. Journal of Religion \& Health,52(2), 418-438.

Ehrhart, M. G. (2004). Leadership and procedural justice climate as antecedents of unit-level organizational citizenship behavior. Personnel Psychology,57, 61-94.

Greenleaf, R. F. (1977). Servant leadership: A journey into nature of legitimate power and greatness. Mahwah, NT: Paulist press.

Hunter, E., Neubert, M. J., Perry, S. J., Witt, L. A., Penney, L. M., \&Weinberger, E. (2013). Servant leaders inspire servant followers: Antecedents and outcomes for employees and the organization. The Leadership Quarterly, 21, 677-691.

Spears, L. C. (Ed.). (1998). Insights on leadership: Service, stewardship, spirit, and servant-leadership. New York, NY: John Wiley \& Sons.

Top, S., Öğe, E., Atan, Ö.,\& Gümüş, S. (2015). Investigation relational levels of intensitybetween paternalistic and servant leadership styles and national culture, organizationalcommitment, and subordinate responses or reactions to the leader style. Procedia-Social \& Behavioral Sciences, 181, 12-22.

Yıldırım, A., \& Şimşek, H. (2006).Sosyal bilimlerde nitel araştırma yöntemleri (5 ${ }^{\text {th }}$ ed.). Ankara: Seçkin Yayıncılık.

Zhou, Y., \& Miao, Q. (2014). Servant leadership and affective commitment in the Chinese public sector: The mediating role of perceived organizational support. Psychological Reports, 115(2), 381-395. 